\author{
Miniailenko Inna \\ $\mathrm{PhD}$, Associate professor \\ Department of Economics, Entrepreneurship and Marketing \\ National University «Yuri Kondratyuk Poltava Polytechnic» \\ Poltava, Ukraine \\ ORCID 0000-0002-0949-206X \\ Byba Volodymyr \\ $\mathrm{PhD}$, Associate professor \\ Department of Economics, Entrepreneurship and Marketing \\ National University «Yuri Kondratyuk Poltava Polytechnic» \\ Poltava, Ukraine \\ ORCID 0000-0002-0388-6199
}

\title{
THE ORGANIZATIONAL-ECONOMIC CONCEPT FORMATION OF ENTERPRISE ENERGY SAVING
}

The main guideline for the development of energy resources in the modern world is the optimization of a complex balanced system of four "E": energy, economy, energy efficiency, ecology.

One of the criteria for an effective energy strategy and energy policy should be reliability and security of energy supply, environmental efficiency and profitability. However, the undisputed facts are that:

- reserves of minerals on Earth are gradually being depleted;

- environmental pollution occurs as a result of human activity;

- nuclear power still does not provide an adequate level of security;

- renewables cannot fully meet the needs of mankind.

The growth of opportunities and aspirations is increasingly confronted with some of the most important laws of the economy nature - the law of resource scarcity or the law of relative scarcity of resources, including energy.

The problem of energy saving has grown from an economic and technological component into a political and social one. Political this problem is because it requires the implementation of state policy in the field of energy efficiency and energy saving, and on the other hand, social, because it requires a change in the principles of human behavior and the adoption of new views, guidelines of society and energy use.

The functioning of the mechanism of implementation of the state policy in the field of energy saving is ensured by the following methods (the use of regulatory legal acts, state programs of energy saving, sectoral and regional programs, etc.), levers - economic and financial (system of prices and tariffs, tax and credit privileges, economic stimulation and financing of energy-saving measures, etc.), instruments (setting standards for the consumption of fuel and energy resources, energy expertise of projects, energy consumption standards, etc.) [1]. 
If we analyze and summarize the experience of domestic and foreign enterprises, we should pay attention to the fact that innovation activity in the country must be carried out through the mechanism of regulation of FER. The investment market in Ukraine is unstable, but given the steady increase in energy prices and maintaining competitiveness in the world market, energy consumption can be reduced through the realization of investments. Such investments bring a number of positive results (Fig. 1).

Energy saving policy is implemented in many countries due to the functioning of the state-private partner. Three main components of an effective energy conservation policy:

- stimulating to save and save energy;

- compulsion to save energy;

- conducting energy conservation programs and events.

To track the issue of energy efficiency, a National Agency has been set up, the main task of which is to ensure effective strategic management in the field of efficient use of energy resources and to coordinate cooperation with local authorities on issues of energy efficiency and energy saving [2].

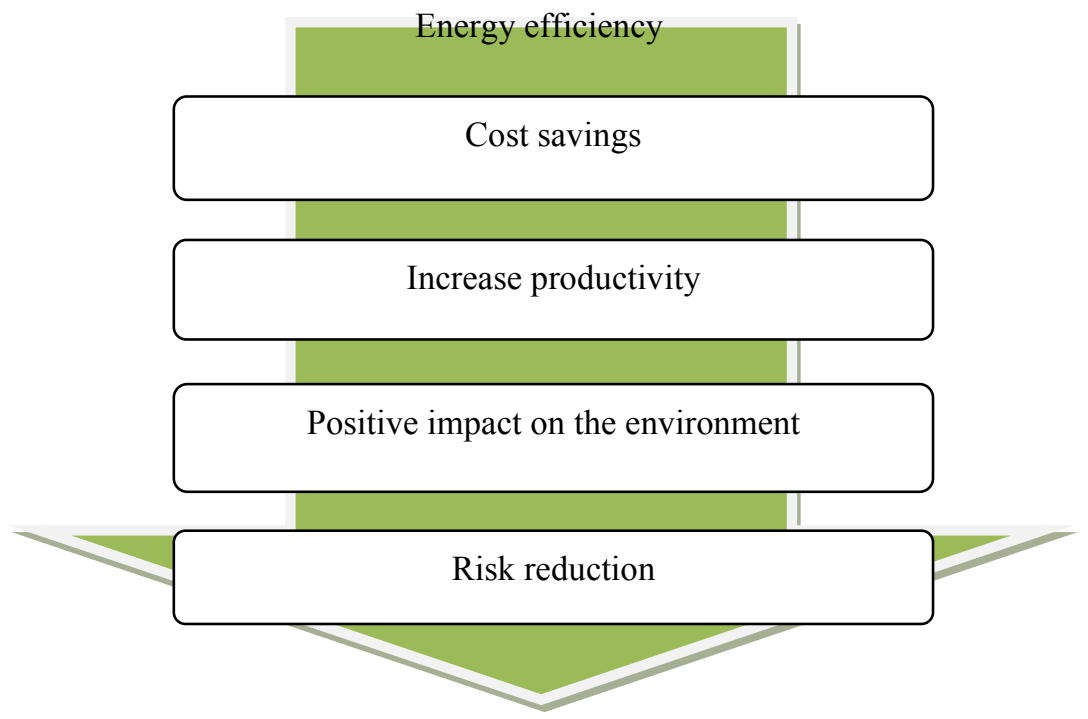

Fig. 1 - Benefits of investing in the development of renewable energy

Source: Developed by the author

The implementation of the energy saving policy is associated with the formation of both positive and negative trends (Fig. 2). 
The positive trends of energy saving policy are:

- orientation towards increasing the production of energy resources;

- increasing the use of non-traditional and renewable energy sources;

- implementation of high-efficiency technologies;

- maximal attraction of energy saving potential;

- adaptation of national legislation to EU norms and standards.

The negative trends in energy conservation policy include:

- continued use of morally and physically outdated fixed assets;

- deepening the dependence of domestic energy on imported energy;

- slow pace of energy intensity economy reduction.

Fig. 2 - Positive and negative trends in energy saving policy

Source: Developed by the author on the basis of [3]

For Ukraine, energy efficiency is a key goal of sustainable development. It can be argued that for our country, energy efficiency is not only energy saving, but also optimization of the ratio of effect (utility, quality, cost, quantity of products produced, quality of life, social comfort) and energy costs required by the energy produced. On September 24, 2010, Ukraine signed the "Energy Community Application Agreement" and on February 1 became a legal member of that Community. By signing this agreement, the country undertakes to:

- realization of landmarks in a certain area;

- the development of an adequate regulatory framework and the liberalization of the energy market in accordance with the terms of the contract.

Having full rights and obligations to the community, Ukraine must fulfill the tasks assigned to it, namely the Directive [4], namely the Electricity Promotion Directive (Table 1).

Therefore, according to the results of the analysis of scientific and legislative sources, it is advisable to formulate the main directions of energy saving:

- refinement and improvement of the current legislation, standardization of energy efficiency of renewable energy sources and fuels;

- optimization of the structure of the energy balance of the state;

- conducting energy audits of energy consumers and energy resources in order to implement energy-saving measures;

- correction of the mechanism of pricing for FER;

- improving the methodology for calculating energy efficiency indicators;

- implementation of mechanisms to support the introduction of FER accounting devices;

- Ukraine's participation in international agreements, projects on energy efficiency issues, attracting significant and long-term investments to ensure 
modernization, sustainable development, security and competitiveness of energy saving;

- development of measures to stimulate the spread of energy management systems in energy-intensive industries; services;

- improving the methodology for facilitating access to energy auditing

- timely payments on the "green tariff";

- adaptation of government mechanisms to the principles and requirements of EU law [6].

Table 1 - Activation factors for state regulation of energy saving in Ukraine

\begin{tabular}{|c|c|}
\hline $\begin{array}{l}\text { Factors of activation of the energy } \\
\text { saving state regulation in Ukraine }\end{array}$ & Directions of implementation \\
\hline $\begin{array}{l}\text { The prospect of further growth of } \\
\text { domestic energy prices }\end{array}$ & $\begin{array}{l}\text { "Roadmap for the implementation of } \\
\text { the Energy Efficiency Directives" }\end{array}$ \\
\hline $\begin{array}{l}\text { The need to increase the } \\
\text { competitiveness of the Ukrainian } \\
\text { economy in the context of increasing } \\
\text { tariffs and prices of final products at the } \\
\text { expense of frequent consumption of } \\
\text { energy }\end{array}$ & $\begin{array}{l}\text { The Law of Ukraine "On Energy } \\
\text { Efficiency" is the setting of priorities } \\
\text { of energy efficiency in accordance } \\
\text { with the Compilation of the basic } \\
\text { norms and requirements of the } \\
\text { European Union on energy } \\
\text { efficiency, as well as the main } \\
\text { national energy laws, including the } \\
\text { Energy Strategy of Ukraine. }\end{array}$ \\
\hline $\begin{array}{l}\text { Tariff growth is a powerful } \\
\text { destabilizing influence on the social } \\
\text { and political sphere, and a decrease in } \\
\text { energy consumption for energy savings } \\
\text { can be seen as a factor that offsets the } \\
\text { rise in energy costs }\end{array}$ & $\begin{array}{l}\text { Law of Ukraine "On Energy Saving } \\
\text { in Buildings", which must comply } \\
\text { with the Directive on Energy } \\
\text { Efficiency of Buildings }\end{array}$ \\
\hline $\begin{array}{l}\text { The threat of a critical impact of energy } \\
\text { shortages, to overcome which is one of } \\
\text { the most priority and effective } \\
\text { mechanisms is to improve energy } \\
\text { efficiency }\end{array}$ & $\begin{array}{l}\text { Discontinue consumer price support } \\
\text { as a negative factor hindering the } \\
\text { implementation of energy efficiency } \\
\text { measures while developing a safety } \\
\text { net for vulnerable consumers }\end{array}$ \\
\hline \multicolumn{2}{|c|}{$\begin{array}{l}\text { Ukraine acts as an attractive market for the sale of technologies and equipment } \\
\text { in the field of energy saving and improving energy efficiency (the market for } \\
\text { energy-saving technologies in the world has already emerged) }\end{array}$} \\
\hline
\end{tabular}

Source: developed by the author based $[5,10]$

The introduction of energy-saving measures at the enterprise is explained by the fact that the entrepreneurs seek to profit from these measures, as well as additional funds from the state and foreign investors. Reasoning for this is that the 
reduction of electricity consumption and natural gas will have a positive effect on the enterprise's income. At the same time, the company will immediately see a significant number of competitive advantages, namely:

- competitiveness with increased energy costs;

- productivity of production;

- the enterprise's dependence on energy prices becomes less and, accordingly, lower the risks of the company;

- Reduction of energy consumption also leads to a reduction of emissions into the atmosphere, thus enhancing the ecological state of the image.

In the future, in the context of the identified areas of energy saving, it is advisable to form an organizational and economic concept of energy saving.

Today, improving energy efficiency of production is one of the main tasks of increasing productivity and reducing cost.

Energy efficiency management is a combination of legislative framework and funding mechanisms, institutional organization and coordination functions, all of which are aimed at supporting the implemented energy saving strategy, policies and programs.

The main objective of an effective energy-saving policy, as an auxiliary element of production, is to ensure that all the conditions of the enterprise's plans are fulfilled.

The effectiveness of energy saving and energy use policies is characterized by the dynamics of relevant indicators.

The factor of effective energy conservation policy is a certain action (a set of measures similar in its orientation), which causes a change in the state of the basic elements of production (change of technology, technology, organization of production, labor and management, qualification of employees and use of qualification skills) as a consequence, to positive or negative changes in energy consumption. All the factors that determine the level of energy saving development and energy efficiency policy are divided into external and internal, relative to the consumer enterprise (Table 2).

One of the most significant factors that focuses on energy consumption is the change in the volume of production of certain types of products. With the increase in the number of products produced, the consumption of energy resources most often increases. However, this is not the case in all cases. The influence of this factor cannot be considered separately from the factor of the structure of manufactured products. With the increase in production of less energy intensive products, the value of the main indicator of energy consumption - energy intensity - will decrease, and with significant structural changes the amount of consumed energy resources may decrease. 
Table 2 - Classification of factors for effective energy conservation and energy efficiency policies

\begin{tabular}{|c|c|c|c|}
\hline \multirow{5}{*}{ 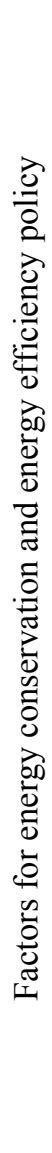 } & & Complex & artial \\
\hline & \multirow{3}{*}{ 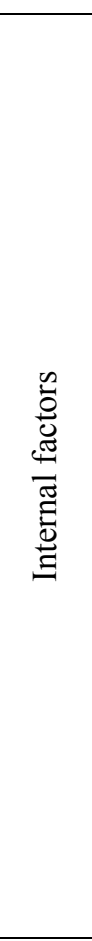 } & $\begin{array}{l}\text { Increasing the } \\
\text { technological } \\
\text { level of enterprise } \\
\text { production }\end{array}$ & $\begin{array}{l}\text { Introduction of new energy-saving } \\
\text { equipment; introduction of new energy- } \\
\text { saving technologies; improvement of } \\
\text { current technology; improvement of } \\
\text { quality of energy resources, choice of } \\
\text { parameters of energy carriers; } \\
\text { introduction of energy efficient energy } \\
\text { sources }\end{array}$ \\
\hline & & $\begin{array}{l}\text { Increasing the } \\
\text { technological } \\
\text { level of enterprise } \\
\text { production }\end{array}$ & $\begin{array}{l}\text { Optimization of the structure of } \\
\text { consumption of energy resources; optimal } \\
\text { distribution of energy loads; the use of } \\
\text { secondary energy resources; improving } \\
\text { the regulation, accounting and control of } \\
\text { energy consumption; improvement of the } \\
\text { system of economic stimulation of } \\
\text { rational use of energy }\end{array}$ \\
\hline & & $\begin{array}{l}\text { Improvement of } \\
\text { the organization } \\
\text { of production and } \\
\text { labor of the } \\
\text { enterprise }\end{array}$ & $\begin{array}{l}\text { Improving the organization and structure } \\
\text { of production; maximum load of power } \\
\text { consuming equipment; change in } \\
\text { production of certain types of products; } \\
\text { reducing costs of marriage; improving the } \\
\text { organization and improving the quality of } \\
\text { repair of energy-consuming equipment }\end{array}$ \\
\hline & 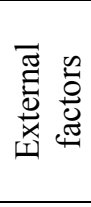 & \multicolumn{2}{|c|}{$\begin{array}{l}\text { Improving legislative regulation of energy consumption; } \\
\text { strengthening of influence of bodies of State supervision on } \\
\text { energy consumption; strengthening market influence; } \\
\text { enhancing the social and environmental importance of energy } \\
\text { savings; uninterrupted power supply }\end{array}$} \\
\hline
\end{tabular}

Source: Developed by the author on the basis of [7 - 9].

Motivational factors are part of the mechanism of interest in achieving maximum economic and social performance. These may be factors of different origins, under the influence of which motivational action takes place. One of the main factors for stimulating the enterprise is the introduction of alternative energy sources, a sharp increase in natural gas prices and price volatility in the gas market, fuel and oil resources.

Increasing the price of fuel and energy resources drives the company to implement energy-saving measures and an energy-saving system. 
The mechanism of development of the concept of energy saving taking into account the characteristics of agricultural enterprises is considered on the example of Kalashnik Private Enterprise.

An analysis of the energy resources used by the Kalashnik Private Enterprise is given in Table 3.

Table 3 - Volume of fuel and energy resources used Kalashnik Private Enterprise for $2016-2018$.

\begin{tabular}{|l|c|c|c|c|c|c|}
\hline \multicolumn{1}{|c|}{ Product } & \multicolumn{2}{|c|}{$\begin{array}{c}\text { The volume of } \\
\text { purchased } \\
\text { resources in 2016 }\end{array}$} & \multicolumn{2}{|c|}{$\begin{array}{c}\text { The volume of } \\
\text { purchased } \\
\text { resources in 2017 }\end{array}$} & \multicolumn{2}{|c|}{$\begin{array}{c}\text { The volume of } \\
\text { purchased resources } \\
\text { in 2018 }\end{array}$} \\
\cline { 2 - 7 } & $\begin{array}{c}\text { Cost } \\
\text { (excluding } \\
\text { grants and } \\
\text { VAT), } \\
\text { UAH. }\end{array}$ & $\begin{array}{c}\text { Cost } \\
\text { (excluding } \\
\text { grants and } \\
\text { VAT), } \\
\text { UAH. }\end{array}$ & & $\begin{array}{c}\text { Cost } \\
\text { (excluding } \\
\text { grants and } \\
\text { VAT), } \\
\text { UAH. }\end{array}$ \\
\hline $\begin{array}{l}\text { Natural } \\
\text { gas, } \\
\text { thousand } \\
\mathrm{m}^{3}\end{array}$ & 159 & 1097026 & 51 & 387090 & 74 & 892411 \\
\hline $\begin{array}{l}\text { Petroleum } \\
\text { products, t: }\end{array}$ & 430 & 6977927 & 472 & 9729898 & 464 & 10302592 \\
\hline petrol & 79 & 1616476 & 68 & 1762281 & 60 & 1815345 \\
\hline diesel fuel & 351 & 5361451 & 404 & 7967617 & 404 & 10121047 \\
\hline
\end{tabular}

Source: Developed by the author

Control over the volume of consumption of fuel and energy resources is carried out by the planning and economic department, which deals with the regulation, planning and accounting of fuel and energy resources. Of great importance is the personal interest of employees in saving energy, and therefore one of the factors may be the existence of a system of economic incentives for rational use of resources and an effective policy of energy conservation and energy use.

When choosing energy-saving measures at an enterprise, it is necessary to explore ways to reduce energy supply. In order to optimize the energy saving potential, the main directions of energy efficiency improvement at the enterprise are taken into account.

Energy-saving measures can minimize unnecessary energy losses, which is now one of the priority areas not only at the state level but also at the level of each individual enterprise. This is due to the scarcity of major energy resources, the rising cost of production, and global environmental problems.

The introduction of energy-saving technologies into the business activities of enterprises is one of the important steps in solving many environmental 
problems - climate change, atmospheric pollution, depletion of fossils, resources and more.

Improvement of energy saving in Ukraine will be accompanied by reduction of energy consumption, conservation of fuel and energy resources, reduction of carbon dioxide emissions, as well as tendencies to decrease the price of electricity for enterprises.

Each state tries to adhere to the benchmarks in order to achieve the Sustainable Development Goals. The SDG was based on the energy security of the state, which in turn consists of the following tasks:

- accelerated development of traditional domestic energy sources (coal, oil, gas) to reduce import dependency;

- reduction of energy consumption by increasing energy efficiency, development of energy-saving technologies;

- development of clean energy technologies, development of alternative energy;

- ensuring the stability of the development of the national energy economy with a reasonable combination of market relations with state regulation, including prospective planning of the development of its industries;

- creation and systematic maintenance of appropriate volumes of strategic reserves of fuel and energy resources in case of various crises and force majeure circumstances [11].

On the basis of the analyzed scientific works, the main goals of sustainable development of the enterprise in ensuring the effective implementation of energysaving technologies were identified (Fig. 3).

Implementation of energy-saving measures for a company can be conditionally divided into several types according to the sphere of operation:

- energy saving measures in production;

- energy saving measures in transport;

- energy saving measures of individual consumption;

- energy saving measures of general consumption [12].

From the above list of energy-saving measures, we distinguish those measures that can bring maximum effect in certain technological and economic conditions, at moderate costs of the enterprise. In order to get energy saving effect, it is possible to modernize the energy saving system and improve the existing technological processes. 


\begin{tabular}{|c|c|c|}
\hline 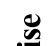 & & Ecological \\
\hline 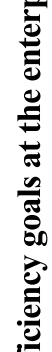 & \multirow{5}{*}{ 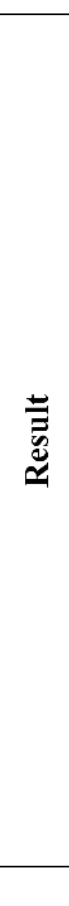 } & $\begin{array}{l}\text { Work with innovative and environmentally } \\
\text { friendly technologies; } \\
\text { Control of the management of hazardous } \\
\text { substances and wastes; } \\
\text { Use of technologies of resource saving, energy } \\
\text { efficiency and energy saving; } \\
\text { Development and implementation of programs to } \\
\text { minimize the impact of production }\end{array}$ \\
\hline $\overrightarrow{0}$ & & Economic \\
\hline 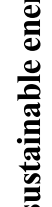 & & $\begin{array}{l}\text { Investments in enterprises and implementation of } \\
\text { international standards; } \\
\text { Continuous improvement of product quality; } \\
\text { Partnership with international financial institutions }\end{array}$ \\
\hline$\ddot{E}$ & & Social \\
\hline 全 & & $\begin{array}{l}\text { Development of regions; } \\
\text { Collaboration with local communities; } \\
\text { Decent conditions; } \\
\text { Safety and health of employees }\end{array}$ \\
\hline
\end{tabular}

Fig. 3 - Sustainable energy development goals at the enterprise Source: Developed by the author

The development of the energy saving program of Kalashnik PE is based on the above calculations (Table 4) and includes the definition of the purpose of implementation, deadline and responsible persons.

Today, in the agrarian sector, the issue of increasing production volumes and increasing crop yields is a top priority. At the same time, agricultural production can be considered as highly efficient, which can be achieved by reducing costs, improving the quality and competitiveness of products. The basis of this method of management can be the efficient and rational introduction of the latest technologies and modern technology in production, namely zero tillage. 
Table 4 - Energy Saving Measures Implementation Program at Kalashnik Private Enterprise

\begin{tabular}{|l|l|l|}
\hline \multicolumn{1}{|c|}{ Activities } & Implementation term & Responsibilities \\
\hline $\begin{array}{l}\text { Implementation of "zero tillage" } \\
\text { of land, no-till technologies, } \\
\text { which is accompanied by }\end{array}$ & $3-5$ years & $\begin{array}{l}\text { Chief engineer, } \\
\text { agronomist, } \\
\text { agronomist- } \\
\text { chemist }\end{array}$ \\
$\begin{array}{l}\text { increased yields, reduced costs of } \\
\text { fuel and lubricants, reduction of } \\
\text { depreciation and depreciation of } \\
\text { basic equipment }\end{array}$ & & \\
\hline $\begin{array}{l}\text { Refurbishment of a gas boiler, } \\
\text { using biomass, which will provide } \\
\text { heating to the office space, which } \\
\text { will reduce energy costs }\end{array}$ & 1 year & $\begin{array}{l}\text { Chief engineer, } \\
\text { boiler manager }\end{array}$ \\
\hline
\end{tabular}

Source: Developed by the author

One of the important steps towards implementation is the diffusion of energy-saving agriculture technologies that will enable:

- to improve the quality of soils, which will be manifested in the restoration of their structure and content of humus, in the elimination of erosion processes, normalization of water and air regimes, the ecological environment;

- to save labor costs, investments and running costs;

- to obtain larger volumes of agricultural products with reduced land use.

For implementation, innovative resource-saving technologies in agriculture were proposed, namely (Table 5):

- precision farming;

- organic farming;

- zero technology;

- minimal technology.

The basic precision agriculture is a system that aims at obtaining from a certain land area the maximum amount of quality and cheaper products by creating a level playing field for all plants of this area without violating environmental standards. Precision farming involves the dosing of fertilizers, water into the soil according to the needs of the plants and the quality of the land.

Because there are heterogeneities within the same field, they are based on the latest technologies. Precise farming requires sophisticated technological support, based on the latest developments in electronic devices and satellite surveillance, and requires various sensors.

Soon organic farming is gaining popularity, namely, organic farming is a system that is mainly based on agroecosystem management, ie not only focused on production management, but also on the implementation of a set of measures that directly affect it in order to achieve economic, environmental and social effects. 
Table 5 - Resource-saving technologies in agricultural production

\begin{tabular}{|l|l|}
\hline The name of the technology & \multicolumn{1}{|c|}{ Characteristics of technology } \\
\hline Precision agriculture & $\begin{array}{l}\text { Dosage of fertilizers, plant protection products, } \\
\text { must be taken into account the local } \\
\text { characteristics of the soil }\end{array}$ \\
\hline Organic agriculture & $\begin{array}{l}\text { Complete rejection of the use of GMO, } \\
\text { antibiotics, fertilizers, agrochemicals. Apply } \\
\text { natural fertilizers, mechanical pest control }\end{array}$ \\
\hline Zero technology & $\begin{array}{l}\text { Mineral application, cultivation, sowing, crop } \\
\text { treatment with plant protection products }\end{array}$ \\
\hline Minimal technology & $\begin{array}{l}\text { Sowing with the introduction of mineral } \\
\text { fertilizers, crop treatment with plant protection } \\
\text { products, collection }\end{array}$ \\
\hline
\end{tabular}

Source: developed by the author [13].

However, agriculture is not only a production system, but also a way of life for the rural population in certain environmental conditions that make up the agroecosystem. This system takes into account the potential detrimental effects on the environment and humans of such synthetic additives as mineral fertilizers and pesticides, genetically modified organisms, and the like. All these methods lead to changes in organic agriculture, namely the preservation of soil fertility, preventing the spread of pests and the growth of diseases. Organic agriculture provides an opportunity to harmonize and harmonize environmental, economic and social goals in the agricultural sector in the future.

The basic principle of organic production is the rejection of genetically modified organisms, antibiotics, agrochemicals and mineral fertilizers. It is thanks to the abandonment of chemical components in the cultivation of the land can improve the biological fund of acreage, restore the balance of nutrients and increase the competitiveness of products on the market. At present, eco-products without the use of nitrates and phosphates are in high demand in the world.

Quite often in advanced agricultural enterprises used the minimum (Minitill) and zero (No-till) cultivation technology. It is thanks to these two technologies of cultivation of acreage that the enterprise can partially or even completely refuse from mechanical tillage of the soil. Its main principles are:

- formation of crop rotation with minimal costs and increase of soil fertility;

- an integrated approach to weeds, pests and plant diseases;

- the use of higher reproduction seed materials, which cooperate with the latest technologies.

By implementing such innovations, it is possible to reduce the cost of depreciation, the cost of fuel and lubricants. After all, for 1 ha of cereals, with a complete cycle of sowing area is spent at zero cultivation of 40-35 liters, depending on the available equipment. 
When choosing the parameters of technological solutions directly involved in agricultural production, where one of the components of the natural-land reclamation geosystem is soil, it is very important to strictly adhere to the technological discipline of minimizing its impact. NO-TILL creates conditions for preserving soil fertility:

- the right solution for sowing, a technical solution to the problem of NOTILL technology, as poor crop yields in most cases can not be compensated, even by effective weed control;

- for NO-TILL technology the tractor must have a powerful motor and hence strong hydraulics (HTZ-17021, HTZ-150-05-09) to provide combined machines for continuous sowing with a lifting force of not less than $2100-2800 \mathrm{~kg}$ and causing extensive damage to the soil by running gear;

- Chemical solutions in NO-TILL technology include activities (weed control) to replace the lack of mechanical tillage.

- with NO-TILL tillage, crushed crop residues are evenly crushed in the process of combining in the field, the soil is untouched until the next crop sowing, which allows to retain more crop residues compared to other minimal cultivation.

Therefore, NO-TILL tillage technology is the basis of soil-protective agriculture, which can suspend soil degradation. The main reason for abandoning the intensive farming system in the leading countries of the world was the spread of erosion of agricultural land due to mechanical cultivation. Studies of leading domestic scientists indicate that in our country annually the area of degraded soils increases by 70.0 thousand hectares. Under these conditions, it is necessary to minimize mechanical tillage, where NO-TILL technology occupies a leading position (Table 6).

Table 6 - List of main types of agricultural work and their impact on the destruction of soil cover

\begin{tabular}{|c|c|c|}
\hline Types of agricultural work & NO-TILL technology & Traditional technology \\
\hline Tillage & - & + \\
\hline $\begin{array}{c}\text { Cultivation with unambiguous } \\
\text { harrowing }\end{array}$ & - & + \\
\hline Sowing & + & + \\
\hline Caring for plants & + & + \\
\hline Harvesting & + & + \\
\hline $\begin{array}{c}\text { Harvesting of post-harvest } \\
\text { residues }\end{array}$ & - & + \\
\hline
\end{tabular}

Source: Developed by the author on the basis of [13]

In order to evaluate the economic feasibility of implementing a NO-TILL tillage system, it is necessary to compare it with the traditional and minimal tillage system. 
Enterprises that use such processing technologies have been researched and analyzed. Energy-saving soil tillage technologies are used by: «Olimp» Limited Liability Company of Kamyanskyi District, «Kyshchenci» Limited Liability Company of Mankovsky District, «Khatsky-Agro» Private Enterprise of Cherkasy District, «LNZ-Agro» Stock Company «Shpola-Agro-Industry» of Shpolyan district and others. These enterprises use «zero» (NO-till) and minimum (Mini-till) tillage technology (Table 7).

Thus, the price of selling 1 ton of grain in «LNZ-Agro» in the analyzed period is higher by UAH 573.86, in «Shpola-Agro-Industry» by UAH 390.94; profit per $1 \mathrm{oz}$ of grain increased by $477,23 \mathrm{UAH}$.

Table 7 - Economic efficiency of grain production in agricultural enterprises

\begin{tabular}{|c|c|c|c|c|c|}
\hline Indicator & $\begin{array}{c}\text { Kalashnik } \\
\text { Private } \\
\text { Company } \\
\text { (Traditional) }\end{array}$ & $\begin{array}{c}\text { LNZ-Agro } \\
\text { Company } \\
\text { (Mini-till) }\end{array}$ & $\begin{array}{c}\text { ShpolaAgro- } \\
\text { Industry } \\
\text { Company } \\
\text { (No-till) }\end{array}$ & $\begin{array}{c}\text { Leviation from Kalashnik } \\
\text { Private Company }\end{array}$ \\
\cline { 5 - 6 } & Company & $\begin{array}{c}\text { ShpolaAgro- } \\
\text { Industry } \\
\text { Company }\end{array}$ \\
\hline Sown area, ha & 2357,3 & 5185,0 & 3263 & $+2827,7$ & $+905,7$ \\
\hline $\begin{array}{c}\text { Production of } \\
\text { grain, c }\end{array}$ & 200565 & 399437 & 164864 & +198872 & -35700 \\
\hline $\begin{array}{c}\text { Productivity, } \\
\text { kg / ha }\end{array}$ & 85,1 & 77,0 & 50,5 & $-8,1$ & $-34,6$ \\
\hline $\begin{array}{c}\text { Production } \\
\text { cost of 1 c, } \\
\text { UAH }\end{array}$ & 111,12 & 198,52 & 221,03 & $+87,40$ & $+109,9$ \\
\hline $\begin{array}{c}\text { The total cost } \\
\text { of 1 c, UAH }\end{array}$ & 115,11 & 211,75 & 256,91 & $+96,64$ & $+141,80$ \\
\hline $\begin{array}{c}\text { The selling } \\
\text { price of 1 c, } \\
\text { UAH }\end{array}$ & 167,55 & 741,41 & 558,49 & $+573,86$ & $+390,94$ \\
\hline $\begin{array}{c}\text { Profit per c, } \\
\text { UAH }\end{array}$ & 52,44 & 529,67 & 301,58 & $+477,23$ & $+249,14$ \\
\hline $\begin{array}{c}\text { Profitability } \\
\text { level, \% }\end{array}$ & 45,6 & 250,1 & 117,4 & $+204,5$ & $+71,8$ \\
\hline
\end{tabular}

The introduction of innovative tillage technologies will result in significant savings of resources (PMM, fertilizers, labor and time costs, reduction of depreciation and other deductions); to increase the profitability of agricultural production; to preserve and restore the fertility of the soil layer (improvement of its chemical, physical and biological qualities, increase of organic matter content in 
the soil); reduce soil erosion (no need to spend extra money to solve this problem); reduce the dependence of the crop on weather conditions; increase crop yields.

The study also showed that through the use of innovative tillage technologies, it is possible to achieve:

- increase of economic effect in grain cultivation and its production;

- the introduction of zero tillage can stabilize the production and competitiveness of grain products;

- introduction of NO-TILL technology of cultivation of sowing allows to prevent land degradation, to preserve and restore soil fertility, to improve ecological state of the environment;

- increasing the popularity of the use of resource-saving technologies in the production of cereals.

The issue of rational use of energy in the context of constantly increasing prices for the main types of energy resources, which have a significant external dependence on suppliers, is particularly relevant. Energy efficiency is generally characterized by high economic efficiency. The savings from the implementation of energy saving measures, as a rule, significantly exceed the cost of the implemented measures already in the medium term. Therefore, the introduction of energy-saving technologies in all spheres of life of the enterprise should become a strategic direction for the development of the economy and social sphere, the transition from traditional types of energy to alternative ones, the introduction of heat generators using biomass [14].

According to the analysis of the company, it was found that energy-saving measures are aimed at technological re-equipment of the energy supply system, and not at modernization of the heating system. Therefore, the use of energysaving technologies is quite advisable, because the monthly increase in gas tariffs and the unstable situation in the country, prompts the company to use alternative energy sources, inexhaustible fuels, crop waste, especially straw [15].

The main activity of the company is plant growing, growing, harvesting and selling products. A large area is occupied by crops of cereals and legumes, which makes it possible to use their biomass rather than burn it in the field or sell it. To implement this energy-saving measure, it is necessary to consider the sowing area of Kalashnik PE (Table 8).

When harvesting, a large amount of straw is left in the fields, in this case it is not only wheat straw, but all the stems and leaves of cereals and agricultural plants after threshing. Such wastes occur annually in large volumes, but are limited to use as litter or roughage in livestock, roofing material or raw materials for building materials, in folk crafts. 
Table 8-Sown areas of cereals and legumes of Kalashnik PE for 2016-2018

\begin{tabular}{|c|c|c|c|c|c|c|}
\hline \multirow[t]{2}{*}{ Product } & \multicolumn{2}{|c|}{$\begin{array}{c}\text { Production output } \\
2016 \\
\end{array}$} & \multicolumn{2}{|c|}{$\begin{array}{c}\text { Production volume in } \\
2017 \\
\end{array}$} & \multicolumn{2}{|c|}{$\begin{array}{c}\text { Production volume } \\
2018 \\
\end{array}$} \\
\hline & $\begin{array}{c}\text { Collection } \\
\text { area, ha }\end{array}$ & $\begin{array}{l}\text { Produced } \\
\text { products, c }\end{array}$ & $\begin{array}{c}\text { Collection } \\
\text { area, ha }\end{array}$ & $\begin{array}{l}\text { Produced } \\
\text { products, c }\end{array}$ & $\begin{array}{c}\text { Collection } \\
\text { area, ha }\end{array}$ & $\begin{array}{l}\text { Produced } \\
\text { products, c }\end{array}$ \\
\hline $\begin{array}{l}\text { Winter } \\
\text { wheat }\end{array}$ & 779 & 32683 & 838 & 401491 & 818 & 41810 \\
\hline \begin{tabular}{|l|} 
Spring \\
barley
\end{tabular} & 526 & 16456 & 483 & 18412 & 392 & 12415 \\
\hline $\begin{array}{l}\text { Winter } \\
\text { barley }\end{array}$ & - & - & 47 & 1851 & 62 & 1940 \\
\hline Oat & 25 & 657 & 38 & 1212 & 38 & 865 \\
\hline
\end{tabular}

Biomass is a biodegradable organic matter that is biodegradable, waste from crop and livestock, forestry and technologically related industries, as well as the organic part of industrial and household waste.

That is, the definition of biomass means its most common varieties, including crop residues of agricultural production (straw, leaves, shavings, etc.) and the forestry industry (firewood, wood chips, etc.); raw materials of energy crops (energy willow, miscanthus, etc.) and agricultural production (silage of corn and other cereals) [16].

For the enterprise, bioenergy is one of the strategic directions for the development of the renewable energy sector, as there is dependence on imported energy sources (Table 9).

Table 9 - Main potential of vegetable waste

\begin{tabular}{|l|c|}
\hline \multicolumn{1}{|c|}{ Kind of fuel } & Energy potential, million tp / year \\
\hline Cereal straw (without maize) & 5,6 \\
\hline Stem, corn cobs on grain & 2,4 \\
\hline Stem, sunflower husk & 2,3 \\
\hline
\end{tabular}

Source: Developed by the author

Vegetable crops and agricultural production, which are a source of energy, must be attributed to non-traditional sources and varieties of energy raw materials, according to legislative documents. Agricultural production is a powerful source of waste generation, which is biomass suitable for energy production [17].

The main varieties of this biomass are straw of different crops, waste of sunflower, corn and some others. Biomass energy has the potential of cereal and rapeseed straw, stalks, baskets and sunflower husks, corn stalks and corn seed kernels. The use of straw to produce heat is a rational way of disposing of its surplus, which is not used for other agricultural purposes. Straw is $\mathrm{CO}_{2}$-neutral and therefore an environmentally friendly source of energy. In the process of straw 
growth, the same amount of $\mathrm{CO}_{2}$ released during its combustion is absorbed, straw is a local fuel, fairly common in agricultural areas, and a by-product of grain production, and is therefore a relatively inexpensive fuel compared to traditional ones. The money paid for the supply of gas, while burning straw, remains in the area and contributes to its development [13].

The widespread use of straw as a feedstock for biofuels contributes to the creation of a new generation of heating devices, namely heat generators, with an Efficiency Ratio ranging from 80 to 90 percent.

Straw-fired boilers are state-of-the-art heat generators in which reliable automation ensures the heating and hot water supply. The straw heat generator is an insulated (thermos), ready-to-operate installation with automatic equipment, providing the optimum mode of combustion of fuel and obtaining hot water with the necessary parameters and providing the required air temperature in the room, the installation of which requires no additional work on the preparation and construction of structures, except for the preparation of the foundation, the installation of the chimney and connection to the existing boiler heating system as the main or backup energy source [18].

Direct combustion technology is the most obvious way to release energy from biomass. It is simple, well-researched and commercially available. There are many types and sizes of direct combustion systems that can burn different types of fuel, including straw bales. In the chemical sense, combustion is the conversion of all organic materials to carbon dioxide and water in the presence of oxygen (usually atmospheric).

The main principle of using the UTEM RAU-2-600 heat generator is the use of biomass, namely straw. Modern heat generators in which reliable automation provides the process of heating and hot water supply. The automation of the boiler provides the necessary parameters of hot water and the required room temperature, as well as the optimum mode of combustion of fuel. In the presence of bale straw with the help of these heat generators it is possible to provide heat to all production facilities. Table 10 shows the characteristics of the heat generator.

The advantages of heat generators include low power consumption (about $0.5 \%$ of thermal power). When the foundation for the heat generator and thermal networks is ready, installation, installation and adjustment of the installation is carried out within one day.

The calculation of the required capital costs for the installation and adjustment of the equipment is given in Table 11 .

The total cost was UAH 2602500. In order to calculate the feasibility of installing a boiler, it is necessary to determine the cost of thermal energy, namely the cost of $1 \mathrm{Gcal}$. In order to replace $1000 \mathrm{~m} 3$ of gas, it takes 3 tons of straw, the cost of 1 ton of straw is $280 \mathrm{UAH}$. 
Table 10 - Characteristics of the heat generator of the UTEM brand RAU-2-600 using biomass

\begin{tabular}{|c|c|c|c|c|}
\hline \multirow[t]{2}{*}{ № } & \multirow{2}{*}{\multicolumn{2}{|c|}{ Options }} & \multirow[t]{2}{*}{$\begin{array}{c}\text { Units } \\
\text { measurement. }\end{array}$} & $\begin{array}{c}\text { UTEM } \\
\text { RAU-2- } \\
600\end{array}$ \\
\hline & & & & Value \\
\hline 1 & \multicolumn{2}{|c|}{ Rated thermal output } & $\mathrm{kW}$ & 600 \\
\hline 2 & \multicolumn{2}{|c|}{ Recommended weight of one download } & $\mathrm{Kg}$ & 1000 \\
\hline 3 & \multicolumn{2}{|c|}{ Straw moisture recommended, up to } & $\%$ & 25 \\
\hline 4 & \multicolumn{2}{|c|}{$\begin{array}{l}\text { Maximum straw consumption per season (180 } \\
\text { days) }\end{array}$} & $\mathrm{T}$ & 900 \\
\hline 5 & \multicolumn{2}{|c|}{ Maximum water temperature, } & $\mathrm{C}$ & 90 \\
\hline \multirow{2}{*}{6} & \multirow[t]{2}{*}{ Overall dimensions } & Heat generator assembly & $\mathrm{M}$ & $5,10 * 3,6$ \\
\hline & & Balls & $\mathrm{M}$ & $2,8 * 3,0$ \\
\hline 7 & \multicolumn{2}{|c|}{ Height to spillway of overflow of expansion tank } & $\mathrm{M}$ & 7,8 \\
\hline 8 & \multicolumn{2}{|c|}{$\begin{array}{l}\text { Diameter of pipes of direct and return network } \\
\text { water }\end{array}$} & $\mathrm{Mm}$ & 100 \\
\hline 9 & \multicolumn{2}{|c|}{$\begin{array}{l}\text { The surface area of heat exchange in the heat } \\
\text { generator }\end{array}$} & M2 & 58,0 \\
\hline \multirow{3}{*}{10} & \multicolumn{2}{|c|}{ Total water capacity of the heat generator } & $\mathrm{L}$ & 41000 \\
\hline & \multicolumn{2}{|c|}{ Weight of the heat generator without water } & $\mathrm{T}$ & 14,2 \\
\hline & \multicolumn{2}{|c|}{ Electricity consumption } & $\begin{array}{c}\mathrm{kW} * \text { year } / \\
\text { day }\end{array}$ & $6,0-10,0$ \\
\hline 11 & \multicolumn{2}{|c|}{ Effectiveness factor } & $\%$ & 82 \\
\hline 12 & \multicolumn{2}{|c|}{$\begin{array}{c}\text { Topic gas temperature when leaving the heat } \\
\text { generator }\end{array}$} & $\mathrm{C}$ & 250 \\
\hline
\end{tabular}

Source: developed by the author based [19]

Table 11 - Capital costs for equipment installation and commissioning

\begin{tabular}{|c|c|}
\hline Costs & Cost, UAH \\
\hline Organizational and administrative & 10000 \\
\hline Design and approval & 300000 \\
\hline Zero Cycle Works & 32500 \\
\hline General construction work & 130000 \\
\hline Supply of equipment & 725000 \\
\hline Delivery + state duty & 80000 \\
\hline Installation of basic equipment & 25000 \\
\hline Commissioning & 50000 \\
\hline Auxiliary equipment & 250000 \\
\hline Total & 2602500 \\
\hline
\end{tabular}

Source: Developed by the author 
The calculations showed that the cost of $1 \mathrm{Gcal}$ of pure heat is $0.378 \mathrm{t}$ or 105.84 UAH. Knowing how much will cost $1 \mathrm{Gcal}$, you can calculate the cost of thermal energy, taking into account all the costs (table 12).

Table 12 - Calculation of cost of thermal energy

\begin{tabular}{|c|c|}
\hline Costs & Cost, UAH \\
\hline Fuel Raw Materials & 105,84 \\
\hline Electricity & 74,2 \\
\hline Diesel fuel & 10,5 \\
\hline Individual entrepreneur & 214,1 \\
\hline Amortization & 40,1 \\
\hline Other & 35,0 \\
\hline Total & 479,49 \\
\hline
\end{tabular}

Thus, the calculation showed that the cost of heat is $479.49 \mathrm{UAH} / \mathrm{Gcal}$. To calculate the efficiency of implementation, it is also necessary to calculate the cost of gas. The tariff for natural gas is 9078.00 for industrial enterprises and other consumers as of June 1, 2018. The calculation showed that $1000 \mathrm{~m} 3$ of gas is $3,892 \mathrm{Gcal}$, and the cost of $1 \mathrm{Gcal}$ of energy for gas will be 2332,48 UAH / Gcal.

In order to provide fuel during the heating period 477 tons of straw is needed, if translated into the value, the amount is $133560 \mathrm{UAH}$.

The most common indicators for evaluating the effectiveness of project decisions are the following indicators: net reported income, profitability ratio, payback period, internal rate of return [20].

Consider their essence:

Net income $N P V$ is the difference between the present value of the net cash flow over the life of the investment project and the amount of investment costs to realize it. It is calculated by the formula:

$$
N P V=\sum_{t=0}^{n} \frac{C F_{t}}{(1+i)^{t}}-\sum_{t=0}^{n} \frac{I C_{t}}{(1+i)^{t}}
$$

$C F_{t}$ - the amount of net cash flow at separate intervals of the total period of operation of the investment project;

IC - the amount of investment costs for the implementation of the investment project;

$i$ - discount rate used;

$n-$ the number of intervals in the total billing period t. 
Profitability Index $(P I)$, which is understood as the ratio of the present value of the net cash flow over the life of the investment project to the amount of investment costs for its implementation. It is calculated by the formula:

$$
P I_{\mathrm{o}}^{A}=\frac{\sum_{i=1}^{n} \frac{C F_{t}}{(1+i)^{n}}}{\sum_{i=1}^{n} \frac{I C_{t}}{(1+i)^{n}}}
$$

Payback period $(P P)$ is the interval of time from the beginning of the project implementation, during which the total revenues from the project implementation and the total project costs are achieved and beyond which the resulting profit remains positive.

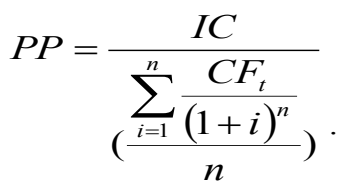

The internal rate of return $(I R R)$ is defined as the discount rate at which the value of the realized proceeds from the sale is equal to the amount of the project cost. IRR describes the rate of return on capital invested in a project. It is calculated by the formula:

$$
I R R=i_{1}+\frac{N P V_{1} \times\left(i_{2}-i_{1}\right)}{\left(N P V_{1}-N P V_{2}\right)}
$$

$N P V_{t}$ - the amount of net cash flow at separate intervals of the total period of operation of the investment project;

$n$ - the number of intervals in the total calculated period $t$.

The discount rate for this project will include a forecast inflation rate for 2018 of $14 \%$, taking into account fluctuations in demand, supply disruption, and poor management of operational processes. In general, we accept a discount rate of $14 \%$ per annum, which will characterize the dynamics of the decrease in the real value of future cash flows and bring them to the initial year of investment, namely 2018 .

Calculation of net present value NPV at a discount rate of $14 \%$ by the formula 1: $N P V=3385302 \mathrm{UAH}$

Profitability Index determined by the formula 2:

$$
P I=3973031 / 2602500=2,3
$$


Payback period is calculated by the formula 3:

$$
P P=10 / 2,3=4,3 \text { years }
$$

Internal rate of return is defined by the formula 4 :

$I R R=14+((3385302 *(26-14) /(3385302-1370531))=14+20,16=34,16 \%$

Calculations of key performance indicators for the implementation of an energy-efficient investment project are summarized in Table 13.

Table 13 - Performance indicators for the implementation of an energyefficient investment project

\begin{tabular}{|c|c|c|}
\hline Investment indicators of the project & \multicolumn{2}{|c|}{ Indicators } \\
\hline Estimated time & Years & 10 \\
\hline IRR Internal Rate of Return & $\%$ & 34,16 \\
\hline Net present value NPV at a discount rate of $14 \%$ & UAH & 3385302 \\
\hline Net present value NPV at a discount rate of $26 \%$ & UAH & 1370531 \\
\hline Payback period & Years & 4,3 \\
\hline
\end{tabular}

Source: Developed by the author

The analysis of the main indicators of the effectiveness of the implementation of the investment project of Kalashnik PE has made the following conclusions:

- net present income at a discount rate of $14 \%$ per year is UAH 3385302 thousand. for a project implementation period of 10 years;

- net adjusted income at a discount rate of $26 \%$ per year is UAH 1370531 thousand. for a project implementation period of 10 years;

- the index of return on investment at a discount rate of $14 \%$ per year is 2.3 ;

- payback period - 4 years 3 months from the moment of project implementation;

- internal rate of return of $34.16 \%$.

Thus, the implementation of the investment project - replacement of the boiler is appropriate for the formation of an effective policy of energy saving of the enterprise, which will reduce energy consumption and have a positive economic effect.

Let us determine the correlation dependence of the energy intensity of the implemented measures as a resultant indicator of cost effectiveness on the indicators of their formation. Yes, we will take the energy intensity indicator as an effective sign - Y. In theory, the factors that can affect the result should reflect both the efficiency of the formation processes and the efficiency of using the enterprise costs. In our opinion, the most influential factors will be:

- yield t / ha;

- mechanization of labor, which characterizes the ratio of the total book value of machines and mechanisms and the average number of employees;

- cost level for $1 \mathrm{UAH}$ of production. 
Denote the identified factors respectively as $\mathrm{X}_{1}, \mathrm{X}_{2}, \mathrm{X}_{3}$. To summarize the output, we summarize them in Table 14.

Table 14 - Baseline data for correlation-regression analysis based on performance of Kalashnik PE

\begin{tabular}{|l|c|c|c|}
\hline \multirow{2}{*}{ Functional variable indication } & \multicolumn{3}{|c|}{ Years } \\
\cline { 2 - 4 } & 2016 & 2017 & 2018 \\
\hline \multicolumn{1}{|c|}{1} & 3 & 4 & 5 \\
\hline Energy intensity of production $(\mathrm{y})$ & 225,95 & 399,56 & 798,04 \\
\hline Yield t / ha. $\left(\mathrm{X}_{1}\right)$ & 4,82 & 5,11 & 4,7 \\
\hline Mechanical Labor UAH / UAH $\left(\mathrm{X}_{2}\right)$ & 302,31 & 228,85 & 263,27 \\
\hline $\begin{array}{l}\text { Cost of 1 UAH of production, UAH / } \\
\text { UAH. }\left(\mathrm{X}_{3}\right)\end{array}$ & 0,41 & 0,40 & 0,49 \\
\hline
\end{tabular}

In this case, the linear model looks like this:

$$
y_{i}=\beta_{0}+\beta_{1} x_{1 i}+\beta_{2} x_{2 i}+\ldots+\beta_{m} x_{m i} .
$$

For sample volume $\mathrm{n}$ we have a system of linear equations:

$$
\begin{aligned}
& y_{1}=\beta_{0}+\beta_{1} x_{11}+\beta_{2} x_{21}+\ldots+\beta_{m} x_{m 1}+\varepsilon_{1}, \\
& y_{2}=\beta_{0}+\beta_{1} x_{21}+\beta_{2} x_{22}+\ldots+\beta_{m} x_{m 2}+\varepsilon_{2} \text {, } \\
& y_{3}=\beta_{0}+\beta_{1} x_{31}+\beta_{2} x_{32}+\ldots+\beta_{m} x_{m 3}+\varepsilon_{3} \text {, } \\
& y_{n}=\beta_{0}+\beta_{1} x_{1 n}+\beta_{2} x_{2 n}+\ldots+\beta_{m} x_{m n}+\varepsilon_{n},
\end{aligned}
$$

$\varepsilon_{i}-$ a random variable having a normal law of distribution with numerical characteristics $M\left(\varepsilon_{i}\right)=0, \quad D\left(\varepsilon_{i}\right)=M\left(\varepsilon_{i}^{2}\right)=\sigma_{\varepsilon}^{2} \quad$ and $\quad K_{i j}=0$. In a vector-matrix form the system takes the following form:

$$
\vec{Y}=X \vec{\beta}+\vec{\varepsilon}
$$

$$
\vec{y}=\left(\begin{array}{c}
y_{1} \\
y_{2} \\
\ldots \\
y_{n}
\end{array}\right) ; \quad \vec{\beta}=\left(\begin{array}{l}
\beta_{0} \\
\beta_{1} \\
\beta_{2} \\
\ldots \\
\beta_{n}
\end{array}\right) ; \quad \vec{\varepsilon}=\left(\begin{array}{c}
\varepsilon_{1} \\
\varepsilon_{2} \\
\ldots \\
\varepsilon_{n}
\end{array}\right) ; \quad X=\left(\begin{array}{cccc}
1 & x_{11} & \ldots & x_{1 m} \\
1 & x_{21} & \ldots & x_{2 m} \\
\ldots & \ldots & \ldots & \ldots \\
1 & x_{n 1} & \ldots & x_{n m}
\end{array}\right) .
$$


The size $X$ matrix $(m+1) \times n$ is called a regression, and the elements $x_{i j}$ of this matrix are called regressors. The equation parameters are constant but unknown. These estimation parameters are statistical point estimates $\beta_{0}^{*}, \beta_{1}^{*}, \beta_{2}^{*}, \ldots \beta_{m}^{*}$ that are obtained by processing the sampling results and are random variables. Thus, the equation corresponds to a statistical estimate:

$$
y_{i}=\beta_{0}^{*}+\beta_{1}^{*} x_{i 1}+\beta_{2}^{*} x_{i 2}+\ldots+\beta_{m}^{*} x_{i m}+\varepsilon_{i} \text {. }
$$

The statistical estimate for the vector $\vec{y}$ will be determined by the vector

$$
\begin{gathered}
\vec{y}=X \vec{\beta}^{*}+\vec{\varepsilon}, \\
\vec{y}=\left(\begin{array}{c}
y_{1} \\
y_{2} \\
\ldots \\
y_{m}
\end{array}\right) ; \quad X=\left(\begin{array}{cccc}
1 & x_{11} & \ldots & x_{1 m} \\
1 & x_{21} & \ldots & x_{2 m} \\
\ldots & \ldots & \ldots & \ldots \\
1 & x_{n 1} & \ldots & x_{n m}
\end{array}\right) ; \quad \vec{\beta}^{*}=\left(\begin{array}{c}
\beta_{0}^{*} \\
\beta_{1}^{*} \\
\beta_{2}^{*} \\
\ldots \\
\beta_{m}^{*}
\end{array}\right) ; \quad \vec{\varepsilon}=\left(\begin{array}{c}
\varepsilon_{1} \\
\varepsilon_{2} \\
\ldots \\
\varepsilon_{n}
\end{array}\right) .
\end{gathered}
$$

The vector of errors will be equal to:

$$
\vec{\varepsilon}=\vec{y}-X \cdot \vec{\beta}^{*}
$$

The least squares method is used to determine the vector $\vec{\beta}^{*}$ components (statistical point estimates of the vector components $\vec{\beta}$ ).

The matrix $X$ contains $m$ linearly independent column vectors, which means that its rank is $m$ and the determinant $\left|X^{\prime} X\right| \neq 0$. Therefore, the matrix $X^{\prime} X$ is inverted.

The variances of the statistical estimates $\beta_{0}^{*}, \beta_{1}^{*}, \beta_{2}^{*}, \ldots \beta_{m}^{*}$ are determined using a correlation matrix for the vector $\vec{\beta}^{\star}$, $K\left(\vec{\beta}^{*}\right)=M\left(\vec{\beta}^{*}-\vec{\beta}\right)\left(\vec{\beta}^{*}-\vec{\beta}\right)^{\prime}$. 
As $\left(X^{\prime} X\right)^{-1}\left(X^{\prime} X\right)=E$, we get it:

$$
\vec{\beta}^{*}=\vec{\beta}+\left(X^{\prime} X\right)^{-1} X \vec{\varepsilon}
$$

Then we have:

$$
\begin{gathered}
\vec{\beta}^{*}-\vec{\beta}=\left(X^{\prime} X\right)^{-1} X^{\prime} \vec{\varepsilon}, \\
\left(\vec{\beta}^{*}-\vec{\beta}\right)^{\prime}=\left(\left(X^{\prime} X\right)^{-1} X^{\prime} \vec{\varepsilon}\right)^{\prime}=(\vec{\varepsilon})^{\prime} X\left(X^{\prime} X\right)^{-1} .
\end{gathered}
$$

So we have:

$$
K\left(\vec{\beta}^{*}\right)=\sigma_{\varepsilon}^{2}\left(X^{\prime} X\right)^{-1}
$$

Since $\sigma_{\varepsilon}^{2}$ it is an $\sigma_{\varepsilon}^{2}$ unknown quantity, it is instead substituted for a point unbiased statistical estimate by analogy with (13).

$$
S_{\varepsilon}^{2}=\frac{\sum\left(\varepsilon_{i}^{*}\right)^{2}}{n-m-1},
$$

where $n$ is the number of observations and $m$ is the number of estimated parameters of multiple linear regression.

The tightness between the signs $Y$ and $X$, where $X=\left(x_{1}, x_{2}, \ldots x_{m}\right)$, is measured by the multiple correlation coefficient $R$, which is a generalization of the paired correlation coefficient $r_{i j}$ and is calculated by the formula:

$$
R=\sqrt{1-\frac{\sum \varepsilon_{i}^{2}}{\sum\left(y_{i}-\bar{y}\right)^{2}}} .
$$

The closer $R$ is to \pm 1 , the better the regression function is selected

$$
y=\alpha\left(x_{1}, x_{2}, \ldots, x_{m}\right) .
$$


In this case $\sum\left(y_{i}-\bar{y}\right)^{2}=\sum y_{i}^{2}-n(\bar{y})^{2}$, and since $\sum\left(y_{i}\right)^{2}=(\vec{y})^{\prime} \vec{y}$, then we finally have:

$$
R=\sqrt{1-\frac{\left(\vec{y}^{*}\right)^{\prime} \vec{y}-\left(\vec{\beta}^{*}\right)^{\prime} X^{\prime} \vec{y}}{(\vec{y})^{\prime} \vec{y}-n(\bar{y})^{2}}} .
$$

Using the MS Excel spreadsheet, we calculate the regression parameters. The matrix of endogenous variables:

$$
\mathrm{X}=\left|\begin{array}{rrrr}
1 & 4,82 & 302,31 & 0,41 \\
1 & 5,11 & 228,85 & 0,4 \\
1 & 4,7 & 263,27 & 0,49
\end{array}\right|
$$

The matrix of exogenous variables:

$$
\mathrm{y}=\left|\begin{array}{l}
225,92 \\
399,56 \\
798,04
\end{array}\right|
$$

We find the product of an endogenous matrix and a transposed endogenous matrix:

$$
\begin{aligned}
& \mathrm{X}^{\mathrm{T}}=\left|\begin{array}{rrr}
1 & 1 & 1 \\
4,82 & 5,11 & 4,7 \\
302,31 & 228,85 & 263,27 \\
0,41 & 0,4 & 0,49
\end{array}\right|
\end{aligned}
$$

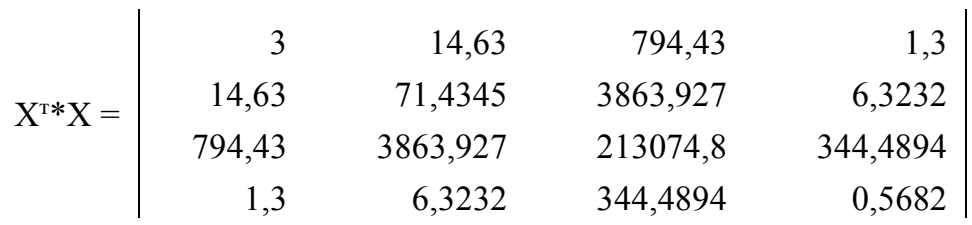

Let's calculate the estimation of least-squares methods: 


$$
\left(X^{\mathrm{T} * X}\right)^{-1}=\left|\begin{array}{rrrr}
4,01 \mathrm{E}+15 & -5,58 \mathrm{E}+14 & -1,95742 \mathrm{E}+12 & -1,79164 \mathrm{E}+15 \\
-5,58 \mathrm{E}+14 & 7,746 \mathrm{E}+13 & 2,71918 \mathrm{E}+11 & 2,48889 \mathrm{E}+14 \\
-1,96 \mathrm{E}+12 & 2,719 \mathrm{E}+11 & 954524195,9 & 8,73685 \mathrm{E}+11 \\
-1,79 \mathrm{E}+15 & 2,489 \mathrm{E}+14 & 8,73685 \mathrm{E}+11 & 7,99692 \mathrm{E}+14
\end{array}\right|
$$

$$
\begin{aligned}
& \mathrm{X}^{\mathrm{T}} \mathrm{Y}=\left|\begin{array}{c}
1423,52 \\
6881,474 \\
369837,2 \\
643,4908
\end{array}\right| \\
& \mathrm{B}=\left(\mathrm{X}^{\mathrm{T} *} \mathrm{X}\right)^{-1} \mathrm{X}^{\mathrm{T}} \mathrm{Y}=\mid \begin{array}{r}
-3712 \\
96 \\
-2,5625 \\
5888
\end{array}
\end{aligned}
$$

So the regression equation will look like this:

$$
y=3712+96 * X_{1}-2,5625 * X_{2}+5888^{*} X_{3}
$$

You also need to calculate the strength of the relationship between the group of factors and the result, Pearson's multiple correlation coefficient (determination). To do this, we use formulas (16) and (17).

With the help of MS Excel editor we will calculate. The theoretical values of the results for 2016 - 2018 have the following vector:

$$
\text { Yteor }=\left|\begin{array}{r}
-1609,86938 \\
-1452,66813 \\
-1050,30938
\end{array}\right|
$$

Error $\dot{\varepsilon}=\mathrm{Y}-$ Yteor has the following vector:

$$
\dot{\varepsilon}=\left|\begin{array}{l}
1835,7894 \\
1852,2281 \\
1848,3494
\end{array}\right|
$$

The multiple correlation coefficient is calculated by the formula 17 :

$$
R=\sqrt{1-\frac{\sum \varepsilon_{i}^{2}}{\sum\left(y_{i}-\bar{y}\right)^{2}}} .
$$


According to the calculation, we obtain that the Pearson correlation coefficient for multiple regression equals:

$$
R=0,816494 \text { or } 81,64 \% \text {. }
$$

Therefore, the power of connection is quite high, that is, it is legitimate to assume that the factors selected cumulatively affect $81.64 \%$ of the result.

For practical application of the constructed model it is necessary to check its adequacy - to determine the statistical significance of the coefficient of determination and the model as a whole using the Fisher test, where the calculated value is determined by the formula:

$$
F=\frac{R^{2}}{1-R^{2}} * \frac{n-m-1}{m},
$$

$R^{2}$ - coefficient of determination,

$n$ - the amount of data observed,

$m$ - number of independent variables.

For a given reliability $\alpha$ and degrees of freedom $m$ and (n-m-1), we find the critical value of the Fisher distribution, using a built-in mathematical integrator in MS Excel. If $F$ is $>F$ critical, then the reliability $\alpha$ can be considered to be statistically significant and the factors included in the regression explain the stochastic dependence of the result sufficiently.

According to the results of calculations we get:

$$
F_{\text {calc. }}=3,499924
$$

Using the built-in Fisher inverse distribution function, for a given reliability $\alpha=0.85$ (probability of adequacy of the economic-mathematical model to the real environment) and $\mathrm{n}=12, m=4$, we have:

$$
F_{\text {crit. }}=2,9959 \text {. }
$$

Because the requirement $F_{\text {calc }}>F_{\text {crit }}$, then it is legitimate to claim that the model is adequate and with a probability of $85 \%$ reflects the reality of the economic environment.

The level of regression shows that yields increase, but not at the expense of technical upgrades, and the soil tillage technology itself provides this result; mechanization of labor will be reduced, which will allow to reduce costs a little and to increase energy efficiency. 
Investigating a fairly large area of acreage, attention was paid to a sufficiently large number of inputs in the production of cereals of different types of fertilizers and rather significant costs for fuel and energy resources. An energysaving measure has been proposed to implement the transition from "traditional" tillage to "zero" tillage.

It is possible to achieve the following result by introducing zero cultivation of acreage:

- reduce the cost of fuel and energy resources in the treatment of acreage;

- reduce wear and tear by reducing load and reducing agricultural work;

- allows to grow environmentally friendly products, which in the future will allow to enter a new market of sales;

- reduces the cost of labor, equipment and fuel;

- cultivation of self-sowing material of the highest grade;

- not to spend additional money for the renovation of the technopark.

Another proposed energy-saving measure at the plant is the replacement of a gas boiler with a UTEM RAU-2-600 brand heat exchanger using biomass, namely straw. To reduce the cost of natural gas, it is advisable to use straw as biofuel.

After calculating the key performance indicators for the implementation of an investment project for Kalashnik PE, we can draw the following conclusions:

- net present income at a discount rate of $14 \%$ per year is UAH 3385302 thousand. for a project implementation period of 10 years;

- net adjusted income at a discount rate of $26 \%$ per year is UAH 1370531 thousand. for a project implementation period of 10 years;

- the index of return on investment at a discount rate of $14 \%$ per year is 2.3; implementation;

- payback period - 4 years 3 months from the moment of project

- internal rate of return $-34.16 \%$.

Thus, the implementation of the investment project is appropriate for the formation of an effective system of energy saving of the enterprise and will allow to reduce the level of energy consumption, to obtain a positive economic effect [21].

Therefore, it is through the implementation of the energy conservation program at Kalashnik PE that it is possible to achieve a reduction in the cost of fuel and energy resources, to achieve a positive economic effect and to reduce the impact of technical means on soil degradation, which will be quite positive for the sustainable development of the enterprise, as social, economic and environmental.

On the basis of the analysis of the program of improvement of energysaving policy of a private enterprise, the prospects of development of the agricultural enterprise were formed taking into account economic, political, social and natural-climatic conditions. Table 15 presents the main prospects and risks of energy efficient enterprise development. 
Table 15 - Prospects and risks of energy efficiency PE «Kalashnik»

\begin{tabular}{|c|c|}
\hline Prospects & Risks \\
\hline \multicolumn{2}{|r|}{ Economic } \\
\hline $\begin{array}{l}\text { 1. Domestic agricultural } \\
\text { producers have the } \\
\text { opportunity to occupy a niche } \\
\text { in the global food market, } \\
\text { namely the niche of organic } \\
\text { production. } \\
\text { 2. Ensuring the internal market } \\
\text { for agricultural products. }\end{array}$ & $\begin{array}{l}\text { 1. The low level of competitiveness of the } \\
\text { domestic agricultural sector in the world food } \\
\text { market. } \\
\text { 2. Poor development of market infrastructure } \\
\text { of domestic food markets. } \\
\text { 3. Lack of effective control over the use of } \\
\text { funds. } \\
\text { 4. Domination of intermediaries. }\end{array}$ \\
\hline \multicolumn{2}{|r|}{ Political } \\
\hline $\begin{array}{l}\text { or } \\
\text { ises. } \\
\text { a legal } \\
\text { gricultural }\end{array}$ & $\begin{array}{l}\text { al protection of agricultural } \\
\text { rison with foreign countries. } \\
\text { tem. } \\
\text { ectronic VAT administration }\end{array}$ \\
\hline \multicolumn{2}{|r|}{ Social } \\
\hline $\begin{array}{l}\text { 1. Financial aid to kindergarten, } \\
\text { school, home for the elderly, } \\
\text { football teams villages } \\
\text { Kalashniki, Ploske and others. }\end{array}$ & $\begin{array}{l}\text { 1. Professional, cultural and spiritual } \\
\text { degradation of the rural population. } \\
\text { 2. Low social living conditions in rural areas. }\end{array}$ \\
\hline \multicolumn{2}{|c|}{ Natural and climatic } \\
\hline $\begin{array}{l}\text { 1. Favorable } \\
\text { conditions. } \\
2 . \text { The presence of }\end{array}$ & $\begin{array}{l}\text { 1. Instability of natural and } \\
\text { conditions. } \\
\text { 2. The use of living organisms. }\end{array}$ \\
\hline
\end{tabular}

Source: Developed by the author

The analysis made it possible to evaluate the efficiency of implementation of the energy conservation program and its main components, namely the readiness of the personnel of the enterprise to interact with the management in order to achieve the set goal, measures for the technological and technological equipment of the production process.

The research showed that through the use of innovative tillage technologies, it is possible to achieve:

- increase of economic effect in grain cultivation;

- the introduction of zero tillage can stabilize the production and competitiveness of grain products;

- introduction of NO-TILL technology of cultivation of sowing allows to prevent land degradation, to preserve and restore soil fertility, and to improve ecological state of the environment;

- increasing the popularity of the use of resource-saving technologies in the production of cereals. 


\section{References:}

1. Heiets' V.M. (2016). Development and interaction of economic and energy policy in Ukraine. Visnyk NAN Ukrainy, vol. 2, pp. $46-53$.

2. Kyrylenko O.V. (2010). Energy saving is a development strategy. Dilovyj visnyk, vol. 2, pp. 8 - 11. [in Ukrainian].

3. Byba V.V., Minialenko I.V. \& Vasiuta, V.B. (2019). Barriers to increase energy efficiency in Ukraine. Zbirnyk naukovykh prats' II Mizhnarodnoi ukraino azerbajdzhans'koi konferentsii «Building Innovations2019». [Proceedings of the II International Ukrainian-Azerbaijan Conference]. Poltava: PoltNTU.430 - 432. [in Ukrainian].

4. The Verkhovna Rada of Ukraine (1994), The Law of Ukraine «About energy conservation», available at: http://zakon3.rada.gov.ua/laws/show/74/94вр. [in Ukrainian].

5. Mykhajlenko I.D. (2006). Energy Saving Policy, Potential Energy Saving Potential in Ukraine. Enerhosberezhenye, vol. 1, pp. 3 - 8. [in Ukrainian].

6. Ukraine's Energy Strategy for the Period until 2035 of August 18, 2017 No 605-p. Retrieved from: https://www.kmu.gov.ua/ua/npas/250250456. [in Ukrainian].

7. Sukhodolia O.M. (2005). Formalization of models of systemic problems managed by energy efficiency policy. Visnyk Natsional'noi akademii derzhavnoho upravlinnia pry Prezydentovi Ukrainy, vol. 4, pp. 233 - 241. [in Ukrainian].

8. Hapryndashvili B.V. (2014). Energy saving as a factor in increasing the competitiveness of industrial enterprises. BiznesInform, vol. 8, pp. $213-$ 217. [in Ukrainian].

9. Dokunina K.I. (2012). Energy saving as a factor in increasing the competitiveness of industrial enterprises. Komunal'ne hospodarstvo mist, vol. 106, pp. 341 - 350. [in Ukrainian].

10. Evaluation and Monitoring for the EU Directive on Energy End-Use Efficiency and Energy Services [Electronic resource]. - Access mode: http://www.evaluateenergysavings.eu/emeees/en/publications/reports/EMEE ES_Final_Report.pdf.

11. Kyrylenko O.V. (2010). Energy saving is a development strategy. Dilovyj visnyk, vol. 2, pp. 8 - 11. [in Ukrainian].

12. Chystov Yu.I. (2010). The essence of the energy-saving mechanism and its multifaceted nature. Visnyk Khmel'nyts'koho natsional'noho universytetu. Ekonomichni nauky. vol. 5, pp. 341 - 344. [in Ukrainian].

13. Nemish P.D. (2013). The essence, estimation and directions of increase of efficiency of mechanism of energy saving of agroindustrial complex. Innovatsijna ekonomika. vol. 7(45), pp. 46 - 53. [in Ukrainian]. 
14. Mykytenko V.V. (2004). Energy efficiency of industrial production: monogr. Ob'iednanyj instytut ekonomik, Kyiv, Ukraine. [in Ukrainian].

15. Vojnarenko M.P., Cherep A.V., Olejnikova L.H. and Cherep O.H. (2010). Innovative development of industrial enterprises: analysis and evaluation: monogr., Khmelnytskyi, Ukraine. [in Ukrainian].

16. Afonchenkova T.M. (2008). Formation of economic mechanism of energy saving by agricultural enterprises: author. diss. SEE of Europe. Univ, Kyiv, Ukraine. [in Ukrainian].

17. Vovk Yu. (2011). Organizational and economic mechanism for managing resource management. Sotsial'noekonomichni problemy $i$ derzhava, vol. 1 (40). http://sepd.tntu.edu.ua/images/stories /pdf/2011/11vyyrvr.pdf. [in Ukrainian].

18. Hladka L.I., Myronenko A.O. (2016). Problematic aspects of energy saving at industrial enterprises of Ukraine, Molodyj vchenyj, http://molodyvcheny.in.ua/files/journal/2016/6/6.pdf. [in Ukrainian].

19. Dzhedzhula V.V. (2013). Formation of organizational and economic mechanism for improving the energy efficiency of industrial enterprises. Ekonomichnyj analiz: zb. nauk. prats'. vol. 12/3, pp. 116 - 118. [in Ukrainian].

20. Serdiuk T.V. (2005). Organizational and economic mechanism of energy saving in industry: monogr. UNIVERSUM-Vinnytsia, Vinnytsia, Ukraine.

21. Byba V.V., Miniajlenko I.V. (2018). Features of financing energysaving measures: cooperation with the EU. Ekonomika ta suspil'stvo. vol. 14, pp. 69 - 75. Access mode: http://economyandsociety.in.ua/journal-14/21-stati14/1668-biba-v-v-minyajlenko-i-v [in Ukrainian]. 